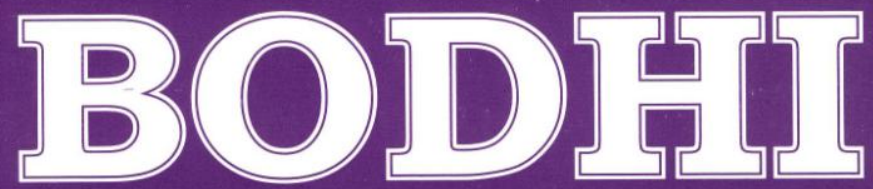

An Interdisciplinary Journal

ISSN: 2091-0479

Department of Languages and Mass Communication School of Arts

Kathmandu University

Bodhi, 4 (1), 100-110. ISSN 2091-0479. (C) 2010 Kathmandu University 


\section{Cultural aesthetics of the contemporary}

- Sanjeev Uprety

The concept of "contemporary" can function as an umbrella term to encompass the cultural forms of both modernity and post-modernity. ${ }^{1}$ In simple words contemporary is what is happening now, including the novels and stories being written, arts and sculptures being exhibited, and music being produced. In a way it is easier to understand the cultural aesthetics of the contemporary - especially in comparison to the loaded terms such as modernity and post-modernity - because we are all living within the shifting frames of our contemporary times. We have all experienced what contemporary means in relation to our lived experiences to the historical present.

The concept of the contemporary is not a fixed entity; rather, it keeps on changing with time. It seems reasonable to suppose that the contemporary cultural practices of the Panchayat era Nepali subjects were different from the contemporary cultural forms of their ancestors living during Malla and Rana periods. Deeply affected by the "global flows," contemporary Nepali cultures in the first decades of the twenty first century are similarly different from the contemporary cultures of the

\footnotetext{
${ }^{1}$ There have been a number of contradictory arguments concerning the theory and praxis of modernity and postmodernity. According to the thinkers like Jean Baudrillard and Francois Lyotard, there is a major gulf between the world views and cultures of modernity and postmodernity. Lyotard, for example, believes that modern culture is characterized by a search for metanarratives; narratives that explain the world and social totality by positing certain universal truths and universal modes of perception and interpretation. Postmodernity, in contrast, challenges the legitimacy of such "universal" truths in favor of "truth(s)" that are multiple, heterogeneous and locally constructed. For a discussion of the cultural aesthetics of modernity see Lyotard (1984, p. 71-82).
} 
Panchayat era. ${ }^{2}$ Each time and space has its own experiences of the contemporary.

In the context of Nepali art, modern Nepali painting has been shaped by the traditions of western painting, first by the styles and techniques of realism and then later by modernism. Some Nepali art critics consider Raj Man Chitrakar who painted for Brian Hudson the first British resident at Kathmandu as the very first modern Nepali painter. Others consider Bhaju Man Chitrakar, the painter who accompanied Rana prime minister Jung Bahadur during his 1850-1 trip to Europe as the first modern Nepali artist. Contemporary art critics like Madan Chitrakar reject both of these claims to argue that the honor of being first modern painters must be reserved for artists like Chandra man Maskey and Tej Bahadur Chitrakar who brought the realistic techniques of portrait painting and landscape from Calcutta in the early 1920s. ${ }^{3}$ Mukesh Malla, another well known contemporary art critic, only partially agrees with Madan Chitrakar concerning this point. According to Malla, while Chandra Man and Tej Bahadur were pioneers who brought the techniques of realistic painting to Nepal, they cannot be called modern artists as their paintings were produced within the frame of realism rather than modernism. ${ }^{4}$ During an interview for the IMAP project, Malla said that Nepali modernism began only after the exhibition of Lain Singh Bangdel's abstract and semi abstract paintings in the $1960 .{ }^{5}$ This argument is not without its problems because both Urmila Upadhyaya Garg and Uttam Nepali had exhibited their

\footnotetext{
${ }^{2}$ For a discussion of "global flows" shaping the politico-cultural terrain of contemporary world see Arjun Appadurai's book Modernity at Large Minneapolis: University of Minnesota press, 1996

${ }^{3}$ See Chitrakar (B.S. 2062, p. 41-7).

${ }^{4}$ See Malla (B.S 2060).

${ }^{5}$ IMAP (Interactive Mapping and Archival Project) was begun with the support of Social Science Baha and Ford Foundation in 2009 with the aim of digitalizing art and theater related materials of Nepal. As part of the project more than two hundred video interviews of fine and theater artists was taken by the end of 2010 .
} 
modernist paintings around this same time. In addition, Gahendra Man Amatya continues to claim that he had exhibited his abstract painting in the 1950s, much before Bangdel's solo show in 1960. Despite these problems, however, Malla argues that Bangdel must be considered pioneer Nepali modernist painter because of the fact that his 1960 show made a major impact on the field of Nepali art, an impact that the earlier work of Amatya was not able produce. A number of young Nepali artists, following Bangdel's example, began to produce modernist painting from mid-1960s onwards and such practice continued into the subsequent decades with the works of modernists such as Krishna Manandhar, Vatsa Gopal Vaidhya, Indra Pradhan, Laxman Shrestha, Shankar Raj Suwal, Vijay Thapa, Kiran Manandhar and others.

From Lain Singh Bangdel and Uttam Nepali to Shashi Bikram Shah and Kiran Manandhar, Nepali modernist painters did not merely copy the techniques of western modernist paintings; rather, they mixed the styles of western modernism--including those of painterly forms such as cubism, expressionism, surrealism, abstrationsim, and abstract expressionism-not only with local themes, but in some cases, also with local drawing paper and locally produced colors. As a result western modernism became localized as it entered Nepal.

Just as techniques of western modernism entered Nepal in the 1950 s and 1960s, similarly forms of western postmodernism began to gain popularity here towards the late 1980s and 1990s. Installation art, performance art, digital art and pop art are some of the examples of such post-modern forms. While modernist art, despite all the experimentation that went with it, was limited to the painterly space of the canvass and the exhibition space of the gallery, installation and performance art took art beyond both the canvass and the gallery. Installation artists used objects in nature and culture to create their art and performance art seemingly dissolved the borders between theater and art. In this sense both of these art forms brought new, radical ideas to 
the field of Nepali art just as they had radicalized western art world in the 1960s. ${ }^{6}$

As in the case of modernist art forms, western postmodernism too became localized as it was reproduced in Nepal. Just as earlier artist s such as Urmila Garg, Gehendra Man Amatya, Lain Singh Bangdel, Uttam Nepali, Krishna Manandhar, Sashi Shah and Vatsa Gopal Vaidhya had used western modernist forms to represent Nepali themes and subjects in 1960s and 1970s, younger artists such as Ashmina Ranjit, Subina Shrestha, Gopal Kalapremi Shrestha, Sujan Chitrakar, Asha Dongol, Bidhata Shrestha, Jupitar Pradhan and Saurganga have used western postmodern forms to interrogate and interpret local political and cultural concerns of Nepal from 1990 onwards. In other words, like modernist cultural forms, postmodern techniques were localized too, shaping the aesthetic forms of contemporary Nepali culture. ${ }^{7}$

Contemporary culture of twenty first century Nepal is not only composed of various layers of traditional, modernist and postmodern art forms, but it also a product of various types of localizations by which western aesthetic forms acquire local textures and colors. This is especially true of the field of Nepali art where traditional, modernist and post-modernist forms are being practiced simultaneously. While the field is composed, at one hand, by the traditional Paubha painting of artists such as Lok Chitrakar and Udaya Charan Shrestha, the same aesthetic arena also holds not only the artworks of modernists like Sashi Shah, Vatsa Gopal Vaidhya, Krishna Manandhar, Kiran Manandhar, Manoj Babu Mishra, Durga Vatsayan and Sashi Kala Tiwari, but also the postmodern installations and performances of Ashmina Ranjit, Sujan Chitrakar, Gopal Kalapremi, Sunil Sigdel, Saur Ganga and Jupiter Pradhan. In other words, the field of contemporary Nepali art is composed

\footnotetext{
${ }^{6}$ See Thapa (2011, p. 17-36).

${ }^{7}$ See Malla (B.S. 2066).
} 
both by the localizations of western forms, and by a simultaneity of tradition, modernity and post-modernity.

Following the establishment of NAFA (National Association of Fine Arts) in 1965, artists taking part in the yearly art competition organized by the association were grouped into two different categories: contemporary and traditional. Traditional art included the art forms such as Poubha and Thanka whereas contemporary art included both realism and various forms of modernism including surrealism and abstraction. In the current context, however, the division between traditional and contemporary art is becoming increasingly problematic. Poubha artists like Udaya Charan Shrestha and Deepak Kumar Joshi have begun to draw poubha that is not traditional in the strict sense but often shaped by the techniques of modernism. Simultaneous use of the traditional subject matter of paubha and realistic use of line drawing is fast becoming the hallmark of Udaya Charan's paintings. Use of surrealistic motif similarly distinguishes Deepak Joshi's poubhas from other artists who are content to draw within the traditional framework. While artists like Charan and Joshi are beginning to draw "contemporary poubha," the very borders of what was known as contemporary art is being challenged and re-written. ${ }^{8}$

When the field was officially divided by NAFA in 1965 into traditional and contemporary art, only realistic and modernist forms were taken as examples of contemporary art. At this point in time, however, postmodernist forms such as installation, performance and video art have emerged as new forms of the contemporary art. How does one determine the borders of contemporary art in such a context? Some installation and performance artists argue-while it is true that modernist forms like expressionism, abstractionism, abstractexpressionism and surrealism used by artists like Uttam Nepali, Krishna Manandhar, Sashi Shah and Kiran Manandhar well represented the contemporary culture of 1960s and 1970s, such

${ }^{8}$ See Shrestha (2011,p. 92-116). 
forms cannot be considered as the sole examples of contemporary art in the early decades of the twentieth century. To understand the flavor and texture of current contemporary culture we need to understand the forms like installation, performance and happening art that became popular after 1990. Following the same argument it can also be said that if painters from Krishna and Kiran Manandhar to Sashi Kala Tiwari are examples of contemporary modern nepali art, then artists like Ashmina Ranjit, Sujan Chitrakar, Sunil Sigdel and Jupitar Pradhan are what might be called "contemporary postmodern" Nepali artists.

Another problem tracing the field is that many Nepali artists have worked in a variety of aesthetic genres. Abstract artists like Mukesh Malla have also produced installations and paubha artists like Udaya Charan and Deepal Joshi are using surrealistic motifs. Celebrated installation and performance artist Ashmina Ranjit is also known for her modernist prints. While there is an increasing presence of surrealistic motifs in Sunil Sigdel's art he is also done some important installation. The question that follows can be asked in the following words: Should be consider such artists as modernists or postmodernists? Or alternatively, should be place them together under the single theoretical umbrella of contemporary art?

Just as it is difficult to accept western modernism as the singular and only model of modern Nepali art, it seems impossible to agree to the view that western postmodern forms such as installation, performance and conceptual art are the only example of current, contemporary art. Just like the borders of western contemporary art, the boundaries of contemporary Nepali art, too, is wide and flexible. While those borders contain traditional forms such as Poubha and Thanka, modernist paintings and postmodernist forms such as installation and performance too are part of the same contemporary mandala. This is to say that artworks ranging from "contemporary" poubhas of Udaya Charan to installations of Ashmina Ranjit, and from Krishna Manandhar's abstract 
paintings to Kiran Manandhar's abstract expressionistic works are all various examples of the contemporary art in the early twenty first century Nepal.

One argument among the art critics of Nepal is that an attempt to place all art forms - from poubha to installation and from realism to surrealism and conceptualism-within a singular category of the contemporary might lead to nothing more than "critical chaos," making it difficult for the critics and general public to understand the specific qualities of each aesthetic genre. In addition, categories like "traditional," "contemporary,' "modern" etc are created not only for the purpose of understanding and analysis but also for national/ international art competition; they are similarly used for granting financial aides to the artists by the government bodies, and by NGOs and INGOs. If the categories of traditional and contemporary arts are not separated from each other, under what rubric should the concerned authorities and institutions hold competitions or grant awards and aids?

It is important to note that western modernist and postmodernist arts had become popular in Europe and in northern America within specific historical and political contexts. While aesthetic forms of western modernity were influenced by the cultural contacts created by colonialism, forms of postmodern art that developed after 1960s were shaped both by the technological changes, and by the logic of identity politics following this decade. Since aesthetic practices cannot be separated from historical, political and technological contexts this leads to a question: is it fair to reject such categories like modernism and postmodernism in favor of a singular heading like the contemporary art or culture? Won't such attempt, by repressing the historical specificities of traditional, modern and postmodern art, paint the singular color of a-historical "contemporary-ness" over all art forms? Art critic Mukesh Malla is of the opinion that the job of a critic consists in making constant differentiations between the borders of traditional, modernist and postmodernist art forms, and the historical 
contexts to which those forms are rooted. As different from this modernist artists like Shankar Raj Suwal and Sashi Shah are of the view that all art that is being produced now-from poubha and thanka to surrealist paintings and installation-should be considered contemporary. Suwal told during an IMAP interview that the semi-abstract paintings that he drew during 1970s and 1980s were examples of the contemporary art of those decades. He added further: "F ollowing those decades I have produced new abstract paintings, with newer styles. These new paintings represent the contemporaneity of the current times. For this reason, I also consider Udaya Charan's poubha, installations of Ashmina and Sujan as well as Ragini Upadhyaya's postmodern prints as other examples of contemporary art. They are all arts of our time, the time we are living through at the present." Sashi Bikram shah also expressed similar thoughts during the interview for the digital archive.

One way to solve the problem might be to create new concepts to signify various art forms under the rubric of contemporary art. For example Udaya Charan's new experiments in Poubha can be named "contemporary poubha" to distinguish them from the "traditional poubha" of Lok Chitrakar. Similarly, installations of Ashmina Ranjit and Sujan Chitrakar could be placed under the category of contemporary installation and Kiran Manandhar's paintings under the title of contemporary abstract expressionism. Such an understanding might help to focus on the differences between the art forms while simultaneously accepting them as various, and differing expressions of contemporary Nepali art. This can lead to a theoretical perspective that acknowledges various art formsfrom traditional poubha to modern poubha, from realistic paintings to surrealistic ones, and from abstraction to installation and performance-as expressions of current, contemporary Nepali art. The borders of contemporary art encompasses tradition, modernity and post-modernity. Global flows are localized within those borders just as western modern and postmodern forms acquire local colors and expressions. 
Cultural forms of western modernism and postmodernism had developed within specific historical and political contexts. Contemporary culture of Nepal, too, is shaped by the historical contexts ranging from the palace massacre, Maoist war and the people's movement of 2006. With future changes in the fields of politics, economy and society, tomorrow's contemporary culture will be different from what we understand and experience now as contemporary. This is not to say that the contemporary cultural forms and experiences of the future will be totally different from that of the present. As Derrida put it, culture much like language is a kind of palimpsest. ${ }^{9}$ It is like a paper where the words, once written, are never erased completely. As the new words, symbols and styles are written, older words and styles are repressed and become invisible to the naked eye. But instead of disappearing, they remain at the unconscious of the text/ culture and keep on influencing the meanings of the new words.

Contemporary culture is like a pamlimpest. New layers of contemporary experiences, in the form of styles, symbols, techniques, will continue to be written in the invisible ground of culture. Older layers will sink 'down' and become partly invisible; but their presence will continue to shape new contemporary experiences. The experience of the new contemporary culture will continue to be shaped by the old which was once contemporary.

${ }^{9}$ For a discussion of the concept of Palimpest see Margins of Philosophy (Derrida, 1982, p. 25-30). 


\section{References}

Appadurai, A. (1996). Modernity at large: Cultural dimensions of globalization Minneapolis: University of Minnesota Press.

Bangdel, D. (2011) Jewels of Newar art: Selections from the collection of Purna and Anjana Shakya. Kathmandu: Bodhisattwa Gallery.

Chitrakar, M. (2004). Tej Bahadur Chitrakar: Icon of a transition. Kathmandu: Teba-Chi Studies Center.

Chitrakar, M. (2005). Nepali chitrakala ko yatra, Lalit 1 (2), 4147.

Derrida, J. (1982). Margins of philosophy London: Harvester Wheatsheaf.

Harrison, C., and Wood, P. (Eds). (1992). Art theory 19001990: An anthology of changing ideas. Oxford: Blackwell.

Kapur, G. (2000). When was modernism: Essays on contemporary cultural practice in India. New Delhi: Tulika Books.

Lyotard, F. (1984). The postmodern condition. Minneapolis: University of Minnesota Press.

Malla, M. (2003). Adhunik Nepali Kala ka samakalin sandarbha. Kathmandu: Lalita Malla.

Malla, Mukesh. (2004). Modern art: Essence and Manifestations. Kathmandu: fineartnepal.com.

Malla, M. (2009). Uttaradhunik Nepali kala ko abhilekh. Kathmandu: Arohan.

Messerschmidt, D. (2004). Against the current: The life of Lain Singh Bangdel, writer, painter and art historian of Nepal. Bangkok: Orchid Press.

Shrestha, B. (2006). RN Joshi: Widening the horizons of Nepali art. Lalitpur: Park Gallery.

Shrestha, P. (2011). Poubha in the twenty first century: A comparative study of the stylistics and iconography of the traditional art of the Kathmandu valley. In Sanjeev Uprety and Robin Piya (Eds.), Urban landscapes, aesthetic productions: Essays on art and theater of the 
Kathmandu valley (pp. 92-116). Kathmandu: Social science Baha.

Thapa, A. (2011). Performance art: Feminine representations as cultural intervention. In Sanjeev Uprety and Robin Piya (Eds.), Urban landscapes, aesthetic productions: Essays on art and theater of the Kathmandu valley (pp.17-36). Kathmandu: Social science Baha.

Dr. Uprety is Reader in Central Department of English, Tribhuvan University, Kirtipur, Kathmandu. 